\title{
Jurnal Bestuur
}

\section{Vol. 7, Issue.1, Agustus, 2019 \\ P-ISSN 2302-3783 \\ This work is licensed under a Creative Commons Attribution 4.o International License (cc-by) \\ Refleksi Paradigma Ilmu Pengetahuan Bagi Pembangunan Hukum Pengadaan Tanah}

\author{
Lego Karjoko ${ }^{a}$, Zaidah Nur Rosidah ${ }^{b}$ I Gusti Ayu Ketut Rahmi Handayanic \\ ${ }^{\text {a.c }}$ Fakultas Hukum, Universitas Sebelas Maret, Surakarta - Indonesia.

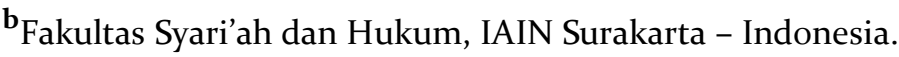 \\ Email Coresponden: legokarjoko@staff.uns.ac.id
}

\begin{abstract}
The purpose of this study is to explain the influence of the positivism paradigm in making land acquisition law and its application which is oriented towards formalism in Indonesia. This type of research is normative and prescriptive legal research, a paradigm that should be used to develop land acquisition law that can realize respect for land rights. To answer the research problem a concept approach is used with the analysis of the syllogism of deduction and interpretation. The paradigm of science as its major premise, while the regulation and application of land acquisition for public use as a minor premise. The results of this study are the positivism paradigm imbued with capitalism causing compensatory injustice and formal injustice in land acquisition for public use. Globalization, through international treaties, causes the importation of the laws of donor countries, which have a capitalist ideology to the Indonesian legal system, which has a family ideology. This harmonization problem if not resolved properly can cause injustice. To realize convergence, it is necessary to consider the use of realistic socio legal theory in land acquisition legal research.
\end{abstract}

Keywords: Positivism, Realistic Legal Socio, Land Acquisition, Justice.

\begin{abstract}
Abstrak
Tujuan penelitian ini adalah untuk menjelaskan pengaruh Paradigma positivisme dalam pembuatan hukum pengadaan tanah dan penerapannya yang berorientasi formalisme di Indonesia. Jenis penelitian ini adalah penelitian hukum normatif dan bersifat preskriptif, paradigma yang seharusnya digunakan untuk membangun hukum pengadaan tanah yang dapat mewujudkan penghormatan terhadap hak atas tanah. Untuk menjawab permasalahan penelitian digunakan pendekatan konsep dengan analisis silogisme deduksi dan interpretasi. Adapun paradigma ilmu pengetahuan sebagai premis mayornya, sedangkan pengaturan dan penerapan pengadaan tanah untuk kepentingan umum sebagai premis minor. Hasil penelitian ini adalah Paradigma positivisme yang dijiwai kapitalisme menyebabkan terjadinya ketidakadilan kompensatoris maupun ketidakadilan formal dalam pengadaan tanah untuk kepentingan umum. Globalisasi, melalui perjanjian internasional menyebabkan terjadinya impor hukum negara-negara donor, yang berideologi kapitalis ke sistem hukum Indonesia, yang berideologi kekeluargaan. Persoalan harmonisasi ini apabila tidak diselesaikan dengan baik dapat menyebabkan ketidakadilan. Untuk mewujudkan konvergensi perlu dipikirkan penggunaan teori socio legal realistik dalam penelitianpenelitian hukum pengadaan tanah.
\end{abstract}

Kata Kunci: Positivisme, Socio Legal Realistik, Pengadaan Tanah, Keadilan.

\section{Pendahuluan}

Dengan mengacu pandangan Guba (E. Guba, 1990: 18) dan Denzin \& Lincoln (Norma K Denzin \& Yvonna S Lincoln , 1994: 107) dapat disimpulkan paradigma adalah sistem keyakinan dasar yang berlandaskan asumsi ontologi, epistomologi, dan metodologi atau dengan kata lain paradigma adalah sistem keyakinan dasar 
sebagai landasan untuk mencari jawaban atas pertanyaan apa itu hakikat realitas, apa hakikat hubungan antara peneliti dan realitas, dan bagaimana cara peneliti mengetahui realitas (Heru Basuki, 2006: 37). Sejak abad pencerahan sampai era globalisasi ini, ada empat paradigma ilmu pengetahuan yang dikembangkan oleh para ilmuwan dalam menemukan hakekat realitas atau ilmu pengetahuan yang berkembang dewasa ini. Paradigma ilmu itu adalah: Positivisme, Postpositivisme (yang kemudian disebut sebagai Classikal Paradigm atau Conventionalism Paradigm), Critical theory (Realism) dan Constructivism (E. Guba, 1990: 18-27).

Paradigma positivisme berkuasa selama berabad-abad setelah pemikiran Aristotelelian dalam Teologi sirna wibawanya. Namun, kekuasaan itu kemudian beralih ke postpositivisme hingga 1980-an masih menampakkan besarnya pengaruh. Sementara itu, paradigma critical theory dan konstruktivisme masih terus menerus berjuang menancapkan pengaruhnya secara lebih kokoh dan kuat sebagai kebenaran ilmu yang diyakini. Di sisi pengembangan keilmuan saat ini belum ada paradigma yang dominan, karena masing-masing memiliki kekuatan dan kelemahan (Agus Salim, 2001: 47).

Paradigma positivisme sangat berpengaruh dalam pembuatan hukum di Indonesia, termasuk hukum pengadaan tanah. Undang-Undang Pokok Agraria memberikan jaminan yang kuat bagi pemegang hak atas tanah apabila hak atas tanahnya dicabut untuk kepentingan umum. Menurut Pasal 18 UUPA, untuk kepentingan umum, termasuk kepentingan bangsa dan Negara serta kepentingan bersama dari rakyat, hak-hak atas tanah dapat dicabut, dengan memberi ganti kerugian yang layak dan menurut cara yang diatur dengan Undang-undang. Dengan perkataan lain pencabutan hak atas tanah hanya dapat dilakukan dengan syarat: pertama, untuk kepentingan umum, kedua, dengan ganti rugi yang layak, ketiga, caranya diatur dengan undang-undang.

Amanat UUPA tersebut di atas belum dilaksanakan oleh Pemerintah. Prinsip penghormatan terhadap hak atas tanah telah diabaikan, yang terjadi justru pelanggaran HAM dalam pengadaan tanah untuk kepentingan umum. Berbagai kasus mengenai proses pengadaan tanah menunjukkan adanya ketidakadilan kompensatoris (Lieke Lianadevi Tukgali, 2010: 172) maupun ketidakadilan formal (Nurhasan Ismail, 2007: 29). Ketidakadilan dalam pengadaan tanah terjadi karena kebijakan pengadaan tanah yang ada selama ini selalu mengakomodasi tuntutantuntutan Negara penyandang modal melalui perjanjian internasional (Satya Arinanto dan Ninuk Triyanti, 2009: 64).

Globalisasi (Gunawan Wiradi, 2000: 177) dalam bentuk pola-pola perdagangan, komunikasi, dan pembangunan merupakan salah satu faktor yang mendorong perubahan hukum suatu bangsa. Bahkan, ketika globalisasi tidak dapat ditolak. Dampak yang ditimbulkan di antaranya, negara-negara bangsa harus berinteraksi dengan cara-cara yang tidak biasa dilakukan. Perubahan hukum suatu bangsa dengan menyesuaikan hukum yang diterima secara internasional karena globalisasi itu menuntut perubahan perilaku warga yang sebelumnya tidak mempola (Hari Purwadi, 2009: 64-65). Pada satu sisi, globalisasi pada hakekatnya adalah gerakan kapitalisme internasional (Gunawan Wiradi, 2000: 177). Pada sisi yang lain paradigma budaya hukum Indonesia adalah budaya hukum kekeluargaan bukan perseorangan (Satjipto Rahardjo, 1999: 47) Persoalan ini membutuhkan harmonisasi. 
Ada tiga persoalan yang belum bisa diselesaikan oleh hukum pengadaan tanah untuk kepentingan umum, yaitu pertama, konsep kepentingan umum, kedua, ganti rugi, ketiga, musyawarah (panitia pengadaan tanah dan prosedur pengadaan tanah). Tulisan ini menguraikan refleksi ragam paradigma ilmu pengetahuan bagi pembangunan hukum pengadaan tanah.

\section{Metode Penelitian}

Jenis penelitian ini adalah penelitian hukum normatif dan bersifat preskriptif, paradigma yang seharusnya digunakan untuk membangun hukum pengadaan tanah yang dapat mewujudkan penghormatan terhadap hak atas tanah. Untuk menjawab permasalahan penelitian digunakan pendekatan konsep dengan analisis silogisme deduksi dan interpretasi. Adapun paradigma ilmu pengetahuan sebagai premis mayornya, sedangkan pengaturan dan penerapan pengadaan tanah untuk kepentingan umum sebagai premis minor.

\section{Hasil dan Pembahasan}

\section{Refleksi Paradigma Ilmu Pengetahuan Bagi Pembangunan Hukum Pengadaan Tanah}

Dalam ilmu sosial perubahan terjadi secara cepat dan dinamis, tergantung pada bukti empiris yang dijakini. Berikut ini akan dipaparkan berbagai unsur yang memiliki kemungkinan untuk dapat dilihat sebagai indikator adanya perubahan dan pengambangan ilmu sebagai berikut (Agus Salim, 2001: 42-46).

1) Ontology

Positivisme memandang kenyataan yang dapat dimengerti itu ada dan dikendalikan oleh hukum dan mekanisme alam yang kekal (realism). Pengetahuan mengenai gejala-gejala disajikan dalam bentuk generalisasi yang bebas waktu dan konteks, juga dalam bentuk hukum sebab akibat, sikap dasar dari paradigma ini adalah mereduksi (reductionist) dan telah ditentukan (deterministic). Postpositivisme memandang kenyataan itu ada, tetapi karena keterbatasan manusia dan sifat degil dari gejala, maka kenyataan itu tidak dapat dimengerti secara sempurna. Ontology dari postpositivis ini disebabkan kenyataan kritis (critical realism) karena sikap dari para pendukungnya yang berkeras menyatakan bahwa kenyataan harus diperiksa secara kritis agar dapat dipahami sesempurna mungkin, tetapi tidak pernah bisa sempurna. Sedangkan, constructivism memandang kenyataan sebagai sesuatu yang telatif (relativit), tempat kenyataan ada dalam bentuk konstruksi mental dari manusia.

2) Epistemologi

Positivisme bersifat dualistis dan objektif, dalam arti si peneliti dan yang diteliti diasumsikan sebagai sesuatu yang saling tidak mempengaruhi atau terpengaruh. Postpositivisme memodifikasi sifat dualistik dan objektif. Dualisme ditinggalkan karena diangap tidak mungkin, namun objektivitas tetap dicoba untuk dipertahankan. Objektivitas eksternal ditekankan di sini, misalnya, apakah temuan sesuai dengan pengetahuan yang sudah ada, juga pemanfaatan masyarakat ilmiah. Konstruktivisme 
bersifat subjektif, di mana temuan merupakan hasil interaksi antara peneliti dengan yang diteliti.

3) Metodologi

Pada positivisme jelas eksperimen dan manipulasi menjadi acuan kegiatan utama. Pertanyaan dan hipotesis dinyatakan dalam bentuk proposisi yang harus diuji untuk mengentahui kebenarannya. Kondisikondisi yang bisa mengacaukan harus dapat dikontrol (dimanipulasi) untuk mencegah pengaruhnya pada keluaran. Postpositivisme memodifikasi eksperimen dan menipulasi, di sini digunakan criticalmultiplism sebagai cara membuktikan kesalahan (falsification), bukan kebenaran tetapi bentuk hipotesis. Metodologi yang digunakan menekankan penelitian yang dilakukan pada keadaan alami, mengumpulkan informasi situasional dan memperkenalkan penemuan sebagai elemen penelitian dan khususnya pada ilmu-ilmu sosial, pemanfaatan cara pandang emic untuk membantu memahami makna dan maksud yang terkandung dalam tindakan manusia, metode yang terkemuka dalam aliran ini adalah metode grounded theory. Semua hal di atas tersebut dilakukan dengan menggunakan teknik-teknik kualitataif. Banyak pendapat yang kini berkembang, ditemukan bukti-bukti yang kuat adanya orientasi yang kuat pada pendekatan subjektif untuk melakukan penelitian dengan memandang objek yang diteliti sebagai sesuatu yang dikonstruksikan secara kurang sempurna dalam benak peneliti, karena kurangnya informasi. Dengan demikian konstruksi itu bisa berubah sejalan dengan proses penelitian. Hal terakhir ini dikenali sebagai paradigma contructivism. Bukti ini juga dikuatlah oleh Charmaz dalam Haig, bahwa dalam kenyataan, keputusan peneliti turut membentuk proses dan hasil penelitian.

4) Axiologi

Pada kelompok positivisme dan postpositivisme, nilai etika dan pilihan moral harus berada di luar proses penelitian. Peneliti harus dapat membebaskan dari dari abjek yang dikaji, karena sikap almiah menghendaki adanya jarak yang menetralisir kedudukan peneliti. Sikap yang diambil oleh kelompok postpositivisme lebih reaktif, sebab sudah mulai terlibat dalam pengambilan keputusan, terlibat dalam diskusi dan sampai pada proses pengambilan kesimpulan. Kelompok konstruktivisme melihat nilai sebagai bagian yang tidak terpisahkan dari suatu penelitian, peneliti adalah transformative-intellectual. Selanjutnya dalam paradigma critical theory, peneliti adalah partisipan aktif yang menjembatani keragaman subjekvitas pelaku sosial.

5) Research Objektive

Positivisme mempunyai tujuan eksplanasi (explanation), sehingga dapat meramalkan dan mengendalikan gejala, baik gejala fisik atau perilaku manusia. Dibandingkan dengan tujuan penelitian dalam paradigma, critical theory mengkritik dan mentransformasikan struktur sosial, politik, budaya, ekonomi, etnik dan gender yang enghambat dan mengeksloitasi manusia, dengan jalan terlibat dalam konfrontasi dan konflik. Sedangkan tujuan dalam penelitian yang berparadigma 
konstruktivisme yaitu bertujuan memahami dan merekonstruksikan konstruksi-konstruksi yang pada saat ini dipegang oleh orang (termasuk si peneliti).

Terkait dengan hukum pengadaan tanah untuk kepentingan umum, perbedaan keempat paradigma ini bisa dilihat dari cara mereka dalam memandang realitas (kepentingan umum, ganti rugi, dan musyawarah) dan melakukan penemuan-penemuan ilmu pengetahuan ditinjau dari tiga aspek pertanyaan: Ontologis, Epistemologi dan Metodologis.

\section{a. Positivisme}

Positivisme merupakan paradigma ilmu pengetahuan yang paling awal muncul dalam dunia ilmu pengetahuan. Keyakinan dasar aliran ini berakar dari paham ontologi realisme yang menyatakan bahwa realitas (kepentingan umum, ganti rugi, dan musyawarah) ada (exist) dalam kenyataan yang berjalan sesuai dengan hukum alam (natural laws). Upaya penelitian adalah untuk mengungkapkan kebenaran realitas yang ada, dan bagaimana realitas tersebut senyatanya berjalan.

Positivis muncul pada abad ke- 19 dimotori oleh Sosiolog Auguste Comte, dengan buah karyanya yang terdiri dari enam jilik dengan judul The Course of Positive Philosophy (1830-1842). Comte menguraikan secara garis besar prinsip-prinsip positivisme yang hingga kono masih banyak digunakan. John Stuart Mill dari Inggris (1843) memodifikasi dan mengembangkan pemikiran Comte dalam sebuah karta yang cukup menimental berjudul $A$ System of Logic. Sedangkan Emile Durkheim (Sosiolog Perancis) kemudian menguraikan satu versi dari positivisme dalam Rule of the Sociological Methods (1895), yang kemudian menjadi rujukan bagi para peneliti ilmu sosial yang beraliran positivisme. (Agus Salim, 2001: 39).

Di Indonesia positivisme, terutama pendekatan sistem, fungsionalisme dan teori modernisasi mempengaruhi kibijakan pengadaan tanah. Pemikiran sistem Parsons ini bertumpu pada pandangan masyarakat sebagai sebuah sistem, masyarakat dengan sendirinya selalu berusaha menjaga integrasi, terdiri dari organ-organ fungsional untuk menjaga keutuhan, bekerja dengan prinsip AGIL (Adaptation, Goal attainment, Integration, Latency), dan selalu mencari keharmonisan. Di sini Parsons mengadaptasi secara selektif karya Durkheim, dengan mengambil asumsi dasar tentang realita sosial dan mengesampingkan pandangan dasar Durkheim yang membedakan anatar Eropa dengan masyarakat non-Eropa. Parsons menempatkan masyarakat dalam koridor evolusi yang sama (Hanneman Samuel, 2010: 71-72).

Di dalam teori Sibernetika Parsons dijelaskan bahwa masyarakat merupakan suatu sistem sosial yang besar, yang di dalamnya terdiri dari subsub sistem yaitu sub sistem budaya, sosial, politik dan ekonomi. Setiap sub sistem mempunyai fungsi primernya sendiri-sendiri. Hubungan Sibernetika (proses kontrol otomatis) antara sub sistem dalam masyarakat berlangsung melalui proses arus informasi yang dari sub sistem dengan tingkat informasi tinggi kepada yang rendah. Namun sebaliknya sub sistem dengan tingkat informasi yang lebih tinggi dikondisikan oleh sub sistem yang lebih rendah kemampuannya memberi informasi. Misalnya sub sistem budaya yang 
mempunyai tingkat informasi yang tinggi akan mengontrol sub sistem yang lain. Demikian sebaliknya sub sistem ekonomi yang mempunyai tingkat energi yang tinggi akan mengkondisikan sub sistem yang lain. Fungsi primer sub sistem politik adalah untuk mengejar tujuan. Setiap masyarakat merupakan satu kesatuan politik artinya masyarakat itu senantiasa berusaha untuk mencapai tujuan yang dianggapnya baik (Satjipto Rahardjo, 2000: 135).

Tujuan negara Indonesia adalah untuk mewujudkan masyarakat adil dan makmur, di mana pembangunan ekonomi telah menjadi pilihan politik nasional untuk mencapai tujuan tersebut. Dari RPJM/RPJP (dahulu GBHN) dapat diketahui bahwa strategi pembangunan yang dijalankan bertujuan untuk mencapai tingkat pertumbuhan ekonomi yang setinggi mungkin. Pembangunan dilaksanakan dengan memanfaatkan bantuan luar negeri sebagai pelengkap (Sritua Arief, 1991:10), yang dalam perkembangan selanjutnya Indonesia menjadi sangat tergantung pada bantuan luar negeri. Mengenai politik perekonomian Indonesia, Moh Hatta menyatakan politik perekonomian jangka panjang meliputi segala usaha dan rencana untuk menyelenggarakan berangsur-angsur ekonomi indinesia berdasarkan koperasi. Di samping itu ada politik kemakmuran berjangka pendek yang sifatnya berlainan dengan ideal kita (Pancasila), yaitu pemberian kesempatan pada perusahaan-perusahaan swasta menjadi kuat, yang berorientasi keuntungan (Mubyarto, 1989: 12-13). Fakta-fakta menunjukkan bahwa dalam ekonomi swasta di mana sebagian besar anggota masyarakat menggantungkan hidupnya, kekuasaan non pribumi dan asing bertambah luas dan kokoh (Sritua Arief, 1991: 14).

Apabila Pancasila (sub sistem budaya) sebagai ideologi bangsa dijadikan landasan filosifis dan landasan praktis dalam menyusun politik ekonomi nasional maka prinsip penghormatan atas tanah menjadi landasan dalam pelaksanaan kewenangan Hak Menguasai Negara dalam pengadaan tanah untuk kepentingan umum. Konseptualisasi Hak Menguasai Negara, dalam UUD 1945 sebelum diamandemen, adalah penempatan Negara sebagai personifikasi rakyat secara keseluruhan (integral). Pada paham Negara integralistik ini juga menempatkan manusia Indonesia sebagai makhluk dwi tunggal di mana kepentingan sosial (kepentingan umum) lebih diutamakan dari kepentingan individu, dengan anggapan bahwa kepentingan umum tersebut telah dengan sendirinya mengandung kepentingan individu. Artinya konsepsi kepentingan umum yang menempatkan kepentingan rakyat sebagai keseluruhan yang digunakan dalam pengadaan tanah (Lilis Nur Faizah, 2007).

Para ilmuwan lokal dari Indonesia mengadopsi perspektif modernisasi, cabang fungsionalisme, untuk menafsirkan situasi sosial mereka dan menerapkan gagasan-gagasan ini untuk membangun masyarakat mereka sendiri. Perbedaan ras di antara ilmuwan, elit penguasa, dan warga biasa semakin kabur (bahkan menghilang) dalam masyarakat pasca kolonial. Perbedaan kelas dan status kini lebih ditentukan oleh kondisi ekonomi, perbedaan tingkat pendidikan, dan penguasaan pengetahuan yang bersumber dari masyarakat maju. Lapisan masyarakat yang tidak mendapat 
pendidikan formal mesti menghadapi kesenjangan kultural denga para teknokrat yang mendapatkan pendidikan tinggi dari masyarakat maju. Para teknokrat ini kini menjadi pengambil keputusan-keputusan penting yang dapat mengubah masyarakat mereka (Hanneman Samuel, 2010: 74-75).

Pemberian makna kepentingan umum dalam peraturan perundangundangan pengadaan tanah didekte pemilik modal melalui perjanjian utang luar negeri. Makna kepentingan umum seiring sejalan dengan orientasi kepentingan pemilik modal. Hal ini menyebabkan hukum pengadaan tanah untuk kepentingan umum menimbulkan ketidakadilan kompensatoris dan formal.

Tabel 1

Hubungan Subernetika Pengadaan Tanah

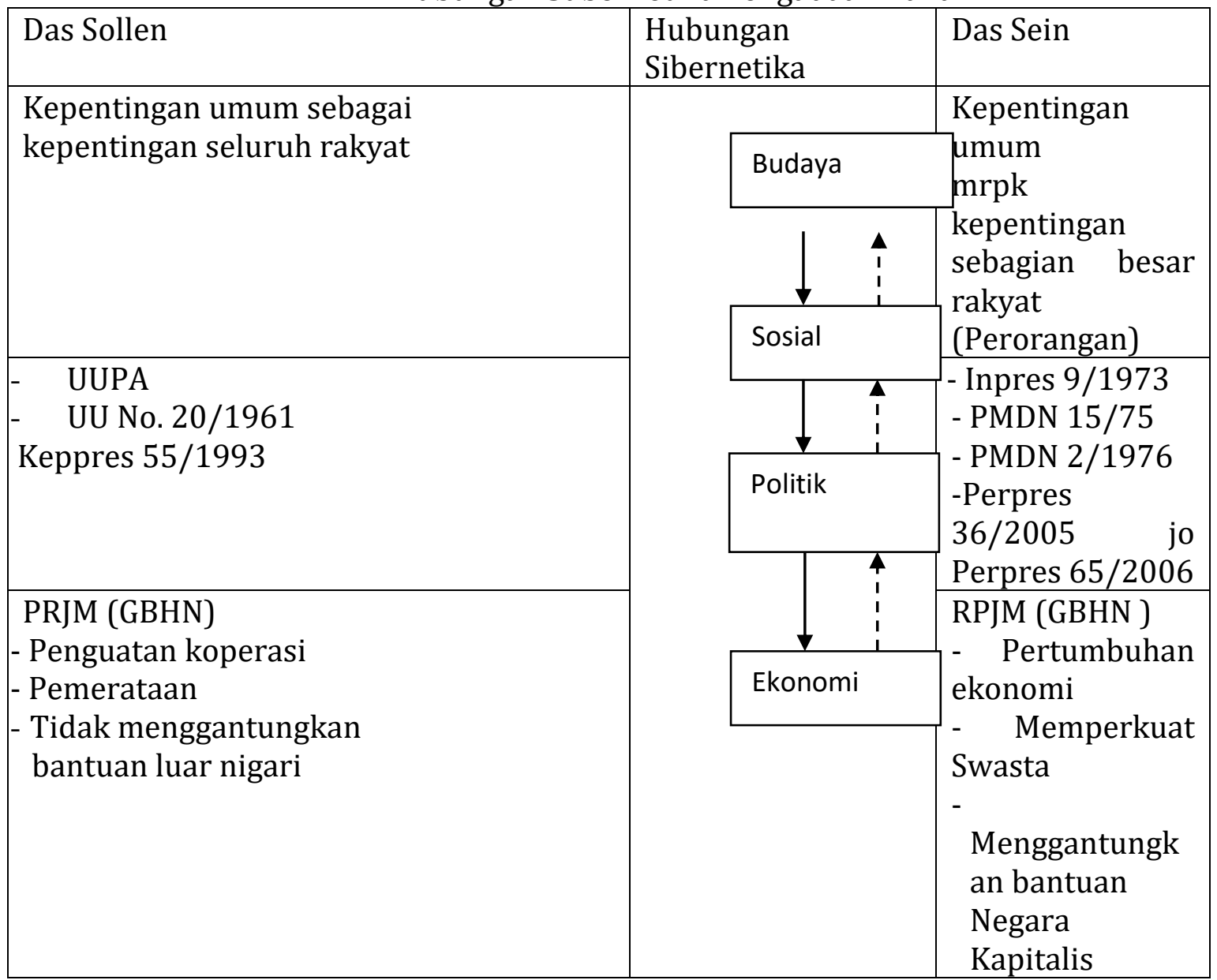




\begin{tabular}{|l|l|}
\hline $\begin{array}{l}\text { Pembangunan berbasis ekonomi } \\
\text { kerakyatan tanpa menggantungkan } \\
\text { bantuan luar negeri }\end{array}$ & -Yang dominan : \\
- & Swasta yang \\
& berbentuk \\
Perseroan \\
Terbatas : \\
& -Pembangunan \\
& ekonomi \\
& berbasis \\
& perjanjian \\
& utang luar \\
& negeri (IGGI, \\
& Bank Dunia, \\
& ADB, IMF, CGI) \\
\hline
\end{tabular}

Hubungan epistemologi ini, harus menempatkan si peneliti di latar belakang untuk mengobservasi hakikat realitas apa adanya untuk menjaga objektivitas temuan. Karena itu secara metodologis, seorang peneliti hendaknya menggunakan metodologi eksperimen empirik atau metode lain yang setara untuk menjamin agar temuan yang diperoleh betul-betul objektif dalam menggambarkan keadaan yang sebenarnya. Mereka mencari ketepatan tinggi, pengukuran yang akurat dan penelitian objektif juga mereka menguji hipotesis dengan jalan melakukan analisis terhadap bilangan-bilangan yang berasal dari pengukuran (Agus Salim, 2001: 40). Dalam perspektif teori modernisasi, kondisi yang paling menghambat Indonesia untuk berkembang mulus adalah keterbelahan kebudayaan dan ketertinggalan ekonomi. Indonesia selalu dianggap sebagai masyarakat dalam masa transisi. Indonesia dipandang sebagai masyarakat yang membutuhkan normalisasi berdasarkan kriteria normalitas, yakni masyarakat yang terbuka dan demokratis dengan landasan sistem kapitalis yang kokoh. Aspek-aspek ini dianggap tak ada di Indonesia (Hanneman Samuel, 2010: 93-95).

Menurut peneliti Amerika hal-hal mendasar dalam normalisasi Indonesia adalah sebagai berikut (Hanneman Samuel, 2010: 96-98). Pertama, modernisasi Indonesia dianggap sebagai sesuatu yang mesti dicapai melalui rekayasa pada berbagai sektor. Di sini penekanan yang kuat diberikan kepada pembangunan ekonomi yang disokong dengan tata kelembagaan institusi politik Indonesia yang kondusif. Kedua, normalisasi dipahami sebagai modernisasi dan pembangunan. Para indonesianis memposisikan AS sebagai aktor yang berpotensi memberi dorongan ekternal dalam membangun sistem dan kelembagaan Indonesia yang dianggap penting dalam proses modernisasi, baik melalui transfer teknologi, pengetahuan, maupun pengalaman membangun tata kenegaraan. Para Indonesianis merekomendasikan pihak eksternal untuk membantu mengembangkan kelas pengusaha Indonesia dalam kerangka politik yang kondusif (demokrasi). Demokratisasi dan pengembangan kelas menengah dianggap sebagai cara yang penting bagi Indonesia untuk beranjak dari ketertinggalannya. 
Ketiga, para Indonesianis meyakini bahwa modernisasi dan pembangunan seyogyanya berlangsung melalui jalan reformasi ketimbang jalur radikal sebagaimana yang digagas Marx. Normalisasi Indonesia tersebut di atas ditampung sejak Orde Baru Suharto berkuasa. Orba yang didominasi militer melaksnakan pembangunan sosial di Indonesia melalui kolaborasi dengan berbagai kelompok kepentingan di masyarakat sipil untuk memuaskan kepentingan masing-masing pihak.

\section{b. Postpositivisme}

Paradigma ini merupakan aliran yang ingin memperbaiki kelemahan positivisme yang hanya mengandalkan kemampuan pengamatan langsung terhadap objek yang diteliti. Secara ontology aliran ini bersifat critical realism yang memandang sama bahwa realitas (kepentingan umum, ganti rugi, musyawarah) memang ada dalam kenyataan sesuai dengan hukum alam, tetapi suatu hal yang mustahil bila suatu realitas dapat dilihat secara benar oleh manusia (peneliti). Oleh karena itu, secara metodologis pendekatan eksperimental melalui observasi tidaklah cukup, tetapi harus menggunakan metode trianggulasi yaitu penggunaan bermacam-macam metode, sumber data, peneliti dan teori (Agus Salim, 2001: 40).

Secara epistemologis, hubungan antara pengamat atau peneliti dengan objek atau realitas yang diteliti tidaklah bisa dipisahkan, seperti yang diusulkan oleh aliran positivisme. Aliran ini menyatakan suatu hal yang tidak mungkin mencapai atau melihat kebenaran apabila pengamat berdiri di belakang layar tanpa ikut terlibat dengan objek secara langsung. Oleh karena itu, hubungan antara pengamat dengan objek harus bersifat interaktif, dengan catatan bahwa pengamat harus bersifat senetral mungkin, sehingga tingkat subjektivitas dapat dikurangi secara minimal (Agus Salim, 2001: 40).

\section{c. Critical Theory}

Aliran ini sebenarnya tidak dapat dikatakan sebagai suatu paradigma, tetapi lebih tepat disebut ideologically oriented inquiry, yaitu suatu wacana atau cara pandang terhadap realitas yang mempunyai orientasi ideologis terhadap paham tertentu. Ideology ini meliputi: Neo-Marxisme, Materialisme, Feminisem, Freireisme, Participatory inquiry, dan paham-paham yang setara. Dilihat dari segi ontology, paham paradigma ini sama dengan postpositivisme yang menilai objek atau realitas secara kritis (critical realism), yang tidak dapat dilihat secara benar oleh pengamatan manusia. Karena itu, untuk mengatasi masalah ini, secara metodologis paham ini mengajukan metode dialog dengan transformasi untuk menemukan kebenaran realitas yang hakiki. Secara epostemologis, hubungan antara pengamat dengan realitas yang menjadi objek merupakan suatu hal yang tidak bisa dipisahkan, karena itu, aliran ini lebih menekankan pada konsep subyektivitas dalam menemukan suatu ilmu pengetahuan, karean nilai-nilai yang dianut oleh subjek atau pengamat ikut campur dalam menentukan kebenaran tentang suatu hal (Agus Salim, 2001: 41). 


\section{d. Konstruktivisme}

Paradigma ini hampir merupakan antitesis dari paham yang melatakkan pengamatan dan objektivitas dalam menemukan suatu realitas atau ilmu pengetahuan. Paham ini menyatakan bahwa paham positivisme dan pospositivisme merupakan paham yang keliru dalam mengungkap realitas dunia. Karena itu, kerangka berpikir kedua paham ini harus ditinggalkan dan diganti dengan paham yang bersifat konstruktif. Secara ontologis, aliran ini menyatakan bahwa realitas itu ada dalam bentuk bermacam-macam konstruksi mental, berdasarkan pengalaman sosial, bersifat lokal dan spesifik dan tergantung pada orang yang melakukannya. Karena itu, suatu realitas yang diamati oleh seseorang tidak bisa digeneralisasikan kepada semua orang seperti yang biasa dilakukan di kalangan positivis atau postpositivis. Karena dasar filosofis ini, maka hubungan epistemologis antara pengamatan dan objek, menurut aliran ini bersifat satu kesatuan, subjektif dan merupakan hasil perpaduan interaksi di antara keduanya (Agus Salim, 2001: 41-42).

Paradigma positivisme, postpositivisme, kritis, dan konstruktivisme mencari kebenaran koherensi, kebenaran korespondensi, dan kebenaran pragmatis. Berdasarkan teori koherensi suatu pernyataan dianggap benar bila pernyataan itu bersifat koheren atau konsisten dengan pernyataan-pernyataan sebelumnya yang dianggap benar. Matematika ialah bentuk pengetahuan yang penyusunannya dilakukan pembuktian berdasarkan teori koheren. Sistem matematika disusun di atas beberapa dasar pernyataan yang dianggap benar yakni aksioma. Dengan mempergunakan beberapa aksioma maka disusun suatu teorema. Di atas teorema maka dikembangkan kaidah-kaidah matematika yang secara keseluruhan merupakan suatu sistem yang konsisten. Plato (427-347 S.M) dan Aristoteles (384322 SW.M) mengembangkan teori koherensi berdasarkan pola pemikiran yang dipergunakan Euclid dalam memyususn ilmu ukurnya. Paham lain adalah kebenaran yang berdasarkan kepada teori korespondensi, di mama eksponen utamanya adalah Bertrand Russell (1872-1970).

Bagi penganut teori koresponndensi maka suatu pernyataan adalah benar jika materi pengetahuan yang dikandung pernyataan itu berkorespondensi (berhubungan) dengan obyek yang dituju oleh pernyataan tersebut. Kedua teori kebenaran ini yakni teori koherensi dan teori korespondensi kedua-duanya dipergunakan dalam cara berpikir ilmiah. Penalaran teoretis yang berdasarkan logika deduktif jelas mempergunakan teori koherensi ini. Sedangkan proses pembuktian secara empiris dalam bentuk pengumpulan fakta-fakta yang mendukung suatu pernyataan tertentu mempergunakan teori kebenaran yang lain yang disebut teori kebenaran pragmatis. Teori pragmatis dicetuskan oleh Charles S.Peirce (1839-1914) dalam sebuah makalah yang terbut pada tahun 1878 yang berjudul "How to Make Our Ideas Clear". Teori ini kemudian dikembangkan oleh beberapa ahli filsafat yang kebanyakan adalah berkebangsaan Amerika yang menyebabkan filsafat ini sering dikaitkan dengan filsafat Amerika. Ahli-ahli filsafat ini diangaranya adalah William James (1842-1910), John Dewey (1859-1952), George Herbert Mead (1863-1931) dan C.I.Lewis. 
Bagi seorang pragmatis maka kebenaran suatu pernyataan diukur dengan kriteria apakah pernyataan tersebut bersifat fungsional dalam kehidupan praktis. Artinya, suatu pernyataan adalah benar, jika pernyataan itu atau konsekuensi dari pernyataan itu empunyai keguanaan praktis dalam kehidupan manusia (Jujun S. Suriasumantri, 1990: 50). Pada satu sisi, globalisasi pada hakekatnya adalah gerakan kapitalisme internasional (Gunawan Wiradi, 2000: 177). Pada sisi yang lain paradigma budaya hukum Indonesia adalah budaya hukum kekeluargaan bukan perseorangan (Satjipto Rahardjo, 1999: 47). Persoalan ini membutuhkan harmonisasi. Penelitian-penelitian sebagai dasar legislasi hukum pengadaan tanah yang berparadigma positivisme akan menimbulkan ketidakadilan kompensatoris dan ketidak adilan formal. Paradigma konstruktivisme tidak bisa menjelaskan persoalan lintas budaya, kekeluargaan dan kapitalis, dalam pengadaan tanah. Dengan adanya dua budaya hukum maka tidak akan terjadi tindakan bersama.

\section{Relevansi Teori Sosio-Legal Realistik Bagi Pembangunan Hukum Pengadaan Tanah}

Brian Z. Tamanaha menjelaskan realistic socio-legal theory sebagai berikut. Menurut James (1975: 37), pragmatisme hanya terdiri atas dua aspek pokok yaitu: sebuah metode penelitian dan sebuah teori kebenaran. Kedua aspek tersebut diperoleh dari pengamatan pragmatist tentang pengalaman. Pekerjaan yang dilakukan secara cerdas terjadi didalam sebuah lingkungan materiil dan sebuah konteks yang melibatkan baik cara-cara bekerja yang sudah ada (mengetahui) maupun sebuah komunitas pelaku; hal ini terjadi didalam praktek. 'Bagi Peirce dan Dewey, penelitian adalah interaksi kerjasama manusia dengan suatu lingkunga; dan kedua aspeknya, intervensi aktif, manipulasi lingkungan aktif, dan kerjasama dengan umat manusia yang lain adalah penting ... Bagi kaum pragmatist, model ini adalah sebuah kelompok peneliti yang mencoba menghasilkan ide-ide yang baik dan mencoba untuk menguji mereka guna melihat mana yang memiliki manfaat' (Putnam 1995: 70-1).

Pandangan operatif tentang pengetahuan melahirkan aspek pragmatisme yang pertama - sebuah metodologi penelitian berbasis ilmu pengetahuan. 'Ciri-ciri pertama yang membedakan pemikiran selanjutnya adalah menghadapi fakta penelitian, hal-hal kecil, dan penelitian yang menyeluruh, observasi' (Dewey 1948: 140). Penelitian ini bukan tanpa tujuan atau acak; hal ini merupakan antisipasi, sarat akan tujuan, 'dengan suatu gagasan yang samar-samar tentang makna kesulitan' (hal. 142, penekanan sejak awal). Akan tetapi, Dewey (hal. 145-6) memperingatkan bahwa 'selalu ada bahaya [penelitian semacam itu] yang akan ditempatkan lebih rendah pada pemeliharaan suatu tujuan atau praduga yang sudah dipahami sebelumnya .... Sudah dilakukan sebelumnya agar sampai kepada suatu hasil yang khusus, hal ini tidak sungguh-sungguh.

Kuncinya adalah 'penelitian yang tidak memihak dan tidak berat sebelah', yang 'berarti bahwa tidak ada akhir tertentu yang ditetapkan sebelumnya untuk menghentikan kegiatan observasi, pembentukan ide-ide dan aplikasi'. Penelitian yang tidak memihak dan tida berat sebelah penting bagi kesuksesan pengetahuan instrumental; sebuah penelitian praduga yang hanya akan memberi tahu anda tentang apa yang sudah anda yakini dan apa yang anda ingin yakini, yang mungkin tidak benar; hanya melalui perhatian terbuka dan hati-hati kepada fakta-fakta 
orang dapat menemukan cara yang mungkin terbaik untuk memahami dan menghadapi persoalan yang ada. Pandangan tentang pengetahuan dan metodologi penelitian berbasis ilmu pengetahuan secara langsung mengarah kepada aspek kedua dari pragmatisme sebuah teori kebenaran. Menurut pendapat Dewey (1948:156, penekanan pada sejak awal):

Jika ide-ide, makna, pemahaman, gagasan, teorim sistem merupakan instrumental bagi sebuah reorganisasi yang aktif dari lingkungan tertentu, terhadap sebuah penghilangan kesulitan dan kebigungan tertentu, maka pengujian validitas dan manfaat mereka terletak dalam penyelesaian pekerjaan ini. Jika mereka berhasil di kantor mereka, mereka terpercaya, bagus, valid, baik, benar. Jika mereka gagal untuk menghilangkan kebingungan, untuk menghapuskan kekurangan, jika mereka menambah kebingungan, ketidakpastian dan kejahatan ketika mereka ditindak, maka mereka benar-benar salah. Penguatan, pembenaran, verifikasi terletak dalam karya, konsekuensi. Tampan adalah tampan itu. Dengan buahnya anda akan mengetahui mereka. Bahwa yang memandu kita sesungguhnya adalah kebenaran - kapasitas yang ditunjukkan untuk panduan semacam itu tentu saja adalah apa yang dimaksud dengan kebenaran.

Kebenaran adalah apa yang bekerja. Kebenaran tidak dapat berubah, dan kebenara baru dapat diciptakan ketika kita bekerja di dunia, menyumbang kepada dan membentuk realita melalui kegiatan-kegiatan kita. Fakta bahwa kita adalah makhluk yang berpikir dan menafsirkan. Disituasikan artinya disituasikan dalam suatu tradisi atau aktivitas budaya, dan konteks dimana kita melihat obyek didalamnya (dengan proyeksi) adalah konteks yang disediakan oleh bahasa, budaya, dan praktek untuk kita. Apa yang membuat mereka menjadi bagian dari 'dasar' adalah fakta bahwa masing-masing aspek tersebut penting bagi kita sebagai makhluk yang berpikir dan menafsirkan - mereka memungkinkan kita untuk berpikir, menafsirkan dan melakukan.

Ilmu pengetahuan memiliki sebuah peran dalam kaitannya dengan fakta dan nilai. Ilmu pengetahuan adalah sistem peneliian yang paling maju yang kita miliki untuk mengungkapkan kondisi-kondisi empiris - fakta - eksistensi kita. Akan tetapi ilmu pengetahuan juga membantu menyediakan suatu cara untuk mengkritik nilai-nilai, seperti yang dikatakan oleh Dewey dan James, yang diperlukan karena 'organ kritikan [dari gagasan umum] bagi kebanyakan pihak merupakan penilaian sebagian, produk adat yang tidak dikritik, situasi peluang dan kepentingan pribadi' (Dewey 1925: 345; lihat juga James 1975: 9). Selanjutnya, pada prakteknya, pengetahuan, ilmu pengetahuan, kebenaran, adalah metode untuk mengkritik keyakinan' (Dewey 1925: 342). Mengetahui bahwa fakta berdiri dalam kaitannya dengan tujuan-tujuan dan keyakinan kita membantu kita secara kritis mengevaluasi tujuan dan keyakinan.

Kehidupan sosial terdiri atas tiga unsur pokok yaitu: 1) perilaku dan 2) makna, 3) yang terwujud dalam konteks material. Sebuah pendekatan pragmatis mengaitkan pada unsur-unsur tersebut sebagai dasar dan terbentuk dari sana. Dalam arti umum, itu berarti mengamati dengan hati-hati apa yang orang lakukan, mencari tahu mengapa mereka melakukannya, dan mencoba memahami bagaimana hal itu dapat terjadi bersama-sama (Brian Z. Tamanaha, 1997: 26-27). 
Keefektifan aturan hukum sangat ditentukan oleh sifatnya yang realistis, dapat diakses, dan jelas. Hukum yang realistis secara sederhana dapat dimaknai dengan merujuk pada pandangan instrumentalis seperti dikemukakan oleh Brian Z,Tamanaha. Pandangan kaum instrumentalis menekankan bahwa hukum dilihat sebagai suatu instrumen kepentingan sosial tertentu (law was seen as an instrument of a particular social interest). Pada karyanya yang lain, Tamanaha mengemukakan bahwa pandangan instrumentalis terhadap hukum melihat hukum, meliputi aturan hukum (legal rules), institusi hukum (legal institutions) dan proses hukum (legal process) - secara sadar dilihat oleh seseorang atau kelompik sebagai 'alat' (tool) atau 'cara' (means) untuk mencapai tujuan. Tujuantujuam yang diletakkan terbuka dan tidak tidak terbatas, bergerak dari tujuan personal ke ideologi sampai tujuan sosial, seperti maksimalisasi kesejahteraan sosial (maximizing social welfare) atau penemuan keseimbangan kepentingan yang bersaing (finding a balance of competing interest) (Hari Purwadi, 2009: 63-64).

Tujuan hukum pengadaan tanah adalah untuk mewujudkan keadilan kompensatoris dan keadilan formal, untuk mewujudkan keseimbangan antara kepentingan umum dan kepentingan pribadi. Dengan demikian teori sosio legal realistik dapat digunakan untuk memberikan preskripsi hukum pengadaan tanah yang dihasilkan dari pengintegrasian budaya hukum kekeluargaan dan kapitalis, mengingat pertama, teori sosio legal realistik tidak menjawab persoalan substansi, tetapi terdiri atas dua aspek pokok yaitu: sebuah metode penelitian dan sebuah teori kebenaran. Kedua aspek tersebut diperoleh dari pengamatan pragmatist tentang pengalaman. Kedua, menurut Koentjoroningrat, kebudayaan nasional Indonesia adalah totalitas dari nilai-nilai, gagasan, dan perilaku manusia Indonesia serta hasil fisiknya, baik yang tradisional maupun ciptaan masa kini, yang semuanya terintegrasi dengan selaras dan bermakna dalam masyarakat Indonesia yang dinamis (Koentjoroningrat, 1992). Ketiga, menurut Paul Scholten sistem hukum ada dalam kesadaran hukum manusia. Jika memang kesatuan dalam hukum adalah unsur yang mutlak harus ada dalam kehidupan kejiwaan manusia, maka apapun isi hukum itu, betapapun juga sistematika dari hukum itu dapat berbeda dari sistematika hukum dari bangsa-bangsa lain dan waktu-waktu lain, niscaya bahwa sistem-sistem itu dapat saling dibandingkan, bahkan bersama-sama mewujudkan suatu kesatuan (Paul Scholten, 2003).

\section{Penutup}

Globalisasi, melalui perjanjian internasional menyebabkan terjadinya impor hukum negara-negara donor, yang berideologi kapitalis ke sistem hukum Indonesia, yang berideologi kekeluargaan. Persoalan harmonisasi ini apabila tidak diselesaikan dengan baik dapat menyebabkan ketidakadilan. Untuk mewujudkan konvergensi perlu dipikirkan penggunaan teori socio legal realistik dalam penelitian-penelitian hukum sumber daya alam, khususnya hukum tanah termasuk hukum pengadaan tanah.

\section{References}

Arief, Sritua, 1991. Perjalanan Nasionalisme Ekonomi Indonesia; Sebuah Tinjauan Kritis. dalam Prisma No. 2 Tahun XX . LP3ES. Jakarta.

Basuki, Heru, 2006, Penelitian Kualitatif untuk Ilmu-Ilmu Kemanusiaan dan Budaya. 
E. G, Guba, 1990. The Paradigm Dialog. Sage. London.

Ismai, Nurhasan, 2007. Perkembangan Hukum Pertanahan Pendekatan Ekonomi Politi., Jakarta : Huma.

K Denzin, Norma \& Yvonna S Lincoln (Editors). 1994. Handbook of Qualitative Research. Sage. London.

Koentjoroningrat. 1992. Pembangunan Kebudayaan nasional. Kompas 10 Oktober. Jakarta.

Lianadevi Tukgali, Lieke, 2010. Fungsi Sosial Hak Atas Tanah Dalam Pengadaan Tanah Untuk Kepentingan Umum. Jakarta: Kertasputih Comunnication.

Mubyarto, 1989. Sistem dan Politik Perekonomian Indonesia dalam Pelaku dan Pilitik Ekonomi Indonesia, Editor Mubyarto dan Revrisond Baswir. Yogyakarta: Liberty.

Nur Faizah, Lilis, 2007. "Perkembangan Konsep Kepentingan Umum dalam Hukum Pengambilalihan Hak atas Tanah di Indonesia (1961-2006)". Skripsi. Yogyakarta: Fakultas Hukum UGM .

Purwadi, Hari, 2009. Reformasi Hukum Nasional : Problem dan Prospeknya, dalam Satya Arinanto dan Ninuk Triyanti, Memahami Hukum Dari Konstruksi Sampai Implementasi. Jakarta: Radjawali Pres.

Rahardjo, Satjipto, 1999. Peningkatan Wibawa Hukum melalui Pembinaan Budaya Hukum. dalam Majalah Hukum Nasional No. 1, BPHN. Jakarta. 2000. Ilmu Hukum. Bandung: Citra Aditya Bakti.

Salim, Agus, 2001. Teori dan Paradigma Penelitian Sosial (dari Denzin Guba dan Penerapannya). Yogyakarta: Tiara Wacana.

Samuel, Hanneman, 2010. Genealogi Kekuasaan Ilmu Sosial Dari Kolonialisme Belanda hingga Modernisme Amerika. Depok: Kepik Ungu.

Scholten, Paul, 2003. De Structure Der Rechtswetenschap, terj. B. Arief Sidharta. Bandung: Alumni.

S. Suriasumantri, Jujun, 1990. Filsafat Ilmu Sebuah Pengantar Populer. Jakarta: Pustaka Sinar Harapan

Wiradi, Gunawan, 2000. Reforma Agraria Perjalanan Yang Belum Berakhir, Yogyakarta: Insist Press.

Z. Tamanaha, Brian, 1997. Realistic Socio-Legal Theory Pragmatism and A Social Theory Of Law. Oxford New York : University Press.. 